\title{
CRITIQUE OF PUBLIC REASON REVISITED: KANT AS ARBITER BETWEEN RAWLS AND HABERMAS
}

\author{
Nythamar Fernandes de Oliveira*
}

\begin{abstract}
SÍNTESE - Trata-se de revisitar o debate RawlsHabermas, em particular, o problema da autonomia politica à luz da apropriação que estes autores nos oferecem do procedimentalismo kantiano. Tanto John Rawls quanto Jürgen Habermas, em suas respectivas concepções de "cultura política" e "esfera pública," partem de uma equivocada atribuição de um fundacionalismo moral em Kant ("fato da razảo") de forma a preservar o princípio normativo de universalizabilidade capaz de assegurar a estabilidade de uma "sociedade bem ordenada" (Rawls) e balizar o procedimentalismo democrático enquanto alternativa para os modelos liberais e republicanos (Habermas).
\end{abstract}

PALAVRAS-CHAVE - Autonomia. Construtivismo. Contratualismo. Democracia. Fundacionalismo. Normatividade. Procedimentalismo.

\begin{abstract}
This article seeks to recast the Rawls-Habermas debate by revisiting the problem of political autonomy in light of John Rawls's and Jürgen Habermas's appropriation of Kantian constructivism in their respective conceptions of "political culture" and "public sphere." It is shown to what extent Rawls and Habermas succeed in preserving the normative principle of universalizability without falling back into what they mistakenly identified with a moral foundationalism (Kant's "fact of reason") and in accounting for the stability of a "well-ordered society" (Rawls) and democratic proceduralism as an alternative to both liberalism and republicanism (Habermas).
\end{abstract}

KEY WORDS - Autonomy. Constructivism. Contractarianism. Democracy. Foundationalism. Normativity. Proceduralism.

\section{Kant als Schiedsrichter zwischen Rawls und Habermas}

John Rawls's and Jürgen Habermas's contributions to modern political theory, in particular, their recasting of the Kantian universalizable principle of autonomy and its political implications, have shown how public reason lies at the heart of democratizing processes and is decisive to the survival of our political, social, and economic institutions in the next century. Both Rawls and Habermas have critically appropriated Immanuel Kant's cognitivist, universalist and emancipatory

* Departamento de Filosofia, PUCRS. I am indebted to Professor Richard J. Bemstein, who directed my post-doctoral research at the Department of Philosophy of the New School for Social Research, New York, in 1997-98, supported by CAPES.

\begin{tabular}{|l|l|l|l|l|l|}
\hline VERITAS & Porto Alegre & v. 45 & n. 4 & Dezembro 2000 & p. 583-606 \\
\hline
\end{tabular}


conception of moral autonomy so as to attempt at an original understanding of publicity and political culture. Kant can thus be said to stand as the arbiter between Rawls and Habermas - als Schiedsrichter zwischen Rawls und Habermas, to paraphrase an article by the young Marx - just as Hobbes's "moralpsychological individualism" and Rousseau's "popular sovereignty" had been previously judged and arbitrated by Kant's political philosophy of justice. ${ }^{1}$ Like Rawls, Habermas shows that normativity must go beyond a merely conventional level of morality and require the structural transformation of legal and economicadministrative institutions so as to make possible the very co-existence of deinocratic differentiated interests. Kant's deontological ethics is thus opposed to both utilitarian and eudaimonistic views of morality and politics, as it serves to construct a nonmetaphysical, political conception of justice (Rawls's "political autonomy") and an intersubjective conception of autonomy (Habermas's "Diskursethik"). Both Rawls and Habermas start from a critical standpoint regarding Kant's fact of reason so as to account for the principle of autonomy in moral and political reasoning. While Rawls seeks to recast the principle of universalizability as a procedural test for maxims, Habermas reformulates Kantian proceduralism in intersubjective, communicative terms. ${ }^{2}$ Unlike Rawls, however, Habermas explicitly embraces Hegel's critique of Kant in his reconstruction of the latter's proceduralism.

On different occasions, Habermas criticized Rawls's theory of justice, especially in his seminal work Moralbewusstsein und kommunikatives Handeln (1983), in his complementary "Remarks on Discourse Ethics" (in Justification and Application, 1993; originally in Erläuterung zur Diskursethik, 1991), in his 1981 essay "Treffen Hegels Einwände gegen Kant auch auf die Diskursethik zu?" (translated and appended to English edition of Moral Consciousness and Communicative Action - hereafter MKH), in the Journal of Philosophy exchange with Rawls ("Reconciliation through the Public Use of Reason: Remarks on John Rawls's Political Liberalism"), and in the companion to his masterpiece Theorie des kommunikativen Handelns, Faktizität und Geltung. ${ }^{3}$ The Rawls-Habermas debate came thus to the fore only after the latter's elaboration of his theory of communicative reason in effect, the two large volumes of TKH reserved one single, peripheral allusion to Rawls (in the Eng. ed., vol. 2, p. 290) - especially through an attempt to integrate

1 Cf. "Luther als Schiedsrichter zwischen Strau $\beta$ und Feuerbach", originally published in the "Anekdota zur neuesten deutschen Philosophie und Publicistik", Band II, 1884, in K. Marx and F. Engels, Werke (Berlin: Dietz Verlag, 1976), vol. 1, pp. 26s.; ET: "Luther as Arbiter between Strauss and Feuerbach," in Writings of the Young Marx on Philosophy and Society, eds. Loyd D. Easton and Kurt H. Guddat (New York: Anchor Books, 1967), pp. 93-95. Cf. my Tractatus ethico-politicus (Porto Alegre: EDIPUCRS, 1999).I am indebted to Prof. Draiton de Souza for pointing out that in fact Marx's authorship has recently been questioned.

2 Cf. J. Rawls, "Themes in Kant's Moral Philosophy" (1983), and J. Habermas, "Morality and Ethical Life: Does Hegel's Critique of Kant Apply to Discourse Ethics?" (1983), both reprinted in Kant and Political Philosophy: The Contemporary Legacy, eds. Ronald Beiner and William J. Booth (New Haven and London: Yale University Press, 1993).

3 I am using the English translations by Thomas McCarthy (Boston: MTT Press, 1984, 1987) and William Rehg (Boston: MIT Press, 1996), respectively abbreviated as TKH and BFN. 
the communitarian critique of Rawls's liberalism (well established by Michael Sandel's Liberalism and the Limits of Justice, 1982) with an alternative conception of democracy (such as the one advocated by Jean Cohen and Andrew Arato in their extensive study of Civil Society and Political Theory, 1992). Hence the official public staging of the Rawls-Habermas debate remains the exchange edited by Michael Kelly (Columbia University, New York) in the Journal of Philosophy (Volume XCII, No. 3, March 1995), reprinted in the 1996 paperback edition of Rawls's Political Liberalism. Habermas's further comments on Rawls's reply were published in Die Einbeziehung des Anderen: Studien zur politischen Theorie (1996) and in the Cardozo Law Review 17/2-3 (Fall 1995), and a forthcoming volume on the Rawls-Habermas debate is to be edited by Michael Kelly. ${ }^{4}$ Besides Kenneth Baynes's seminal study on the Normative Grounds of Social Criticism - a comparative study of the theory of justice in Kant, Rawls, and Habermas - Thomas McCarthy and Rainer Forst have contributed to an in-depth evaluation of this ongoing discussion. ${ }^{5}$ Grosso modo, according to Habermas, Rawls's theory of justice is flawed in at least three specific points: (1) the original position does not appear to account for the impartiality required by deontological principles of justice; (2) the distinction between questions of justification and questions of acceptability is blurred and neutralized by the Rawlsian conception of justice, weakening its validity claims; (3) by constructing the constitutional state in function of the primacy of basic liberal rights over the democratic principle of legitimation, Rawis undermines his intent of reconciling the liberties of the moderns with the liberties of the ancient.s As expected, Rawls resorts to his later distinction between what would be a comprehensive view of justice - such as Habermas's - and his own political conception of justice, as exposed in Political Liberalism. It seems that both procedural devices of representation (Habermas's ideal speech situation and Rawls's original position), inspired by Kant's categorical imperative (particularly, its principle of universalizibility) and supposedly reformulated in nonfoundationalist, normative terms, remain decisive for any serious evaluation of their critical remarks on each other's theoretical claims. While the theory of communicative action claims to ground meaning, reference, and truth or validity upon practical reason in a quasi-transcendental version of Kant's procedural formalism, Ralws's theory of justice denies any role to be played by truth in the practical realm and

4 I also benefitted from the photocopied material for the Program for the Study of Law, Philosophy and Social Theory, at the NYU School of Law, during Professor Habermas's lectures on "Retrospective Comments on 'Faktizität und Geltung'," "On the Internal Relation between the Rule of Law and Democracy," "On the Cognitive Content of Morality," and "May We Understand the Validity of Moral Judgments as an Analogue to Truth?," October 23 and 30, 1997.

5 Kenneth Baynes, The Normative Grounds of Social Criticism: Kant, Rawls, Habermas (Albany: SUNY Press, 1992); Thomas McCarthy, "Kantian Constructivism and Reconstructivism: Rawls and Habermas in Dialogue," Ethics 105 (October 1994): 44-63; Rainer Forst, Kontexte der Gerechtigkeit: Politische Philosophie jenseits von Liberalismus und Kommunitanismus (Frankfurt am Main: Suhrkamp, 1994). Hereafter, respectively NG, KCR and KG. See also by R. Forst, "Die Pflicht zur Gerechtigkeit" in the excellent commentary collection of essays on the Theory of Justice edited by Otfried Höffe, Eine Theorie der Gerechtigkei (Berlin: Akademie Verlag, 1998), pp. 187-208. 
confines justice to the political sphere, in particular, to the basic structure of a liberal-democratic society qua unified system of social cooperation among moral persons (i.e., free and equal humans). Both Rawls's and Habermas's conception of state and society seems thus inseparable from their respective conceptions of the self. Both Rawls and Habermas fail to elaborate on this basic correlation, perhaps because of their programmatic concern to avoid foundationalist articulations of the problem of human nature (the metaphysical foundations thematized, in classical terms, by philosophical anthropology) with ethics and politics, i.e. how the animal rationale discovers herself as a zoon politikon. To be sure, Habermas's conception of Lebenswelt and its articulation within his theory of society must be regarded as an attempt to account for the intersubjective, sociolinguistic constitution of the self qua human being and citizen. And Rawls's early remarks on Kohlberg's moral psychology anticipates Habermas's reconstructive turn as the latter departs from psychoanalytical approaches and a subject philosophy of the self towards Piagetian developmental analyses in the seventies, coinciding with the so-called linguistic turn. ${ }^{6}$ Still, both authors seem to be evasive when they are challenged by their critics to take into account the "concrete other" and her complex, empirical otherness, cutting across the taken-for-granted differentiations of private and public spheres. This can be perceived in Rawls's response to Habermas's criticisms. Although he recapitulates all his procedural formulations, Rawls focuses his reply on remarks (2) and (3) of his interlocutor. Rawls observes that, to the surprise of many readers, "public reason" in his political liberalism must not be confused with the "public sphere" invoked by Habermas, making a rather unusual distinction between the public and nonpublic. The conception of an "overlapping consensus" is thus decisive to bring together Rawls and Habermas on the constituting intersubjectivity of the social world lived out by civil society, at the same time that one opposes their nuanced conceptions of publicity - which Rawls formulates in terms of a political culture and of a "background culture." As opposed to a simplistic reading of Rawls's shift from his earlier formulations of a theory of justice and the political constructivism of his later liberalism, following the communitarian critique, I think this debate must be recast in the conceptual terms of both authors' critical, political appropriation of Kant's conception of autonomy.

Rawls's political conception of justice can be valued by its critical appropriation of Kant's procedural constructivism, in opposition to Hobbes's conception of justice as mutual advantage or regulation of interests, on the one hand, and to Rousseau's (failure to) undertaking an account of the infallible "volonté générale," on the other. Hence the renewal of the contractarian issue - in terms of foundations, in Rawls's attempt at a non-foundationalist theory and in contrast with Habermas's critique of contractarianism and natural law - attests to their sub-

- Cf. J. Habermas, Zur Rekonstruktion des Historischen Materialismus (Frankfurt am Main: Suhrkamp, 1976). 
scription to Kant's "arbitration" beween Locke and Rousseau. ${ }^{7}$ As Habermas quotes from Kant's Rechtslehre:

The legislative authority can be attributed only to the united will of the people. Because all right and justice is supposed to proceed from this authority, it can do absolutely no injustice to anyone. [...] only the united and consenting will of all - that is, a general and united will of the people by which each decides the same for all and all decide the same for each - can legislate. (BFN 472)

Although Habermas criticizes Rawls's problematic shift from a Kantian, liberal contractarianism towards a pluralist, political culture, both authors share in the concern to maintain Kant's universalizibility without its foundationalist aporias. Thus, starting from the continuity between Rawls's earlier formulation of a comprehensive doctrine of justice as fairness in $\mathrm{TJ}$ and his later political conception of justice in PL, it can be shown to what extent Rawls succeeds in maintaining the normative principle of universalizability without falling back into the moral foundationalism of Kant's "fact of reason" and accounting for the stability of a "wellordered society," where are met the demands of rational bargaining in the arbitration of conflicting interests. ${ }^{8}$ And yet, it must be recalled that, for Kant, political life, just as sociability itself, cannot be rationally conceived without resorting to a theory of morality rationally grounded in the very conception of autonomy or as pure practical reason being self-determined qua willing what ought to be freely willed. Although one seems to be either begging the question or moving back to square one, it is the problem of "vindicating reason", as Onora O'Neill put it, that must be tackled here: as one attempts to avoid foundationalism, one is inevitably caught in the self-referentiality of a critical standpoint that posits problems rather than provides axiomatic solutions, is historically reflexive (circular), and nevertheless remains open-ended. ${ }^{9}$ Rawls's political liberalism must therefore be approached in its dual foundations of a contractarian theory of political obligation and of a procedural theory of justice. Even in his earlier attempt at a nonmetaphysical recasting of Kant's proceduralism, Habermas outlines the Diskursethik device in light of Rawls's TJ, especially the two steps of justification - the principle of universalization ( $\mathrm{U}$ ) and its universal validity - based on a transcendentalpragmatic demonstration of universal and necessary presuppositions of argumentation. Habermas's critique of Kant, parallel to Rawls's study of the deduction in the Stanford conference, ${ }^{10}$ avows that "we may no longer burden these arguments with the status of a priori transcendental deduction along the lines of Kant's cri-

7 This problem is elaborated by Habermas's essay "The Classical Doctrine of Politics in Relation to Social Philosophy," in Theory and Practice (Boston: Beacon, 1973).

B Cf. J. Rawls, A Theory of Justice (Cambridge University Press, 1971); Political Liberalism (New York: Columbia University Press, 1993; Paperback edition, 1996). Hereafter respectively abbreviated as TJ and PL.

9 Cf. Onora O'Neill, "Vindicating Reason", in P. Guyer (ed.), Cambridge Companion to Kant. Cambridge University Press, 1992, p. 280-308.

10 J. Rawls, "Themes in Kant's Moral Philosophy," in Eckart Förster, ed., Kant's Transcendental Deductions (Stanford University Press, 1989). 
tique of reason."(MKH 116). It is in this context that Habermas asserts that his "universalization principle can be understood on the model of Rawls's reflective equilibrium as a reconstruction of the everyday intuitions underlying the impartial judgment of moral conflicts of action". Habermas maintains that his proposed formulation of the $\mathrm{U}$ principle is even more fundamental (and nonfoundational) than any other versions of cognitivist, universalist and formalist views, including (peut-être même surtout) Rawls's - whose theory of justice fits the second and third criterion but fails to be consistently "cognitivist" in that it holds the dualistic separation of truth and justice (MKH 120). And yet Rawls's influence upon the device of procedural representation in the theory of communicative reason is implicitly recognized by Habermas. Habermas also points to Rawls's contribution to the pragmatism inherent in Lawrence Kohlberg's moral psychology - Habermas even quotes Kohlberg's fourfold formula of moral reasoning ("impartiality, universalizibility, reversibility, prescriptivity") (MKH 119).

By placing the Rawls-Habermas dialog at the heart of the ongoing debate among universalists in their opposition to communitarians' and noncognitivists' critique of liberalism, I hope to contribute to elucidating the nature of morality and political philosophy in their correlation with the classical question of human nature as it has been critically recast since Kant's critique of metaphysics. According to this view, political philosophy cannot account for the nature and justification of political institutions without presupposing a universalizable, normative conception of morality, itself constitutive of the human person. As Richard Bernstein remarked as early as 1983 ,

A new conversation is now emerging among philosophers - a conversation about human rationality - and as a result of this dialogue we are beginning to gain a new understanding of rationality that has important ramifications for both theoretical and practical life. ${ }^{11}$

Such is the Kantian thrust of this view, as opposed to the communitarian grounding of ethics and political philosophy on the tradition and context out of which discursivity itself takes place. Grosso modo, both universalists and communitarians can be called "cognitivist," insofar as they agree on the possibility of knowing the foundations of moral principles and the necessity of coming up with some moral theory. In short, there must be objectivity in moral reasoning, as one seeks to avoid the pitfalls of both foundationalism and relativism. In this sense, both teleological (i.e., virtue ethics and utilitarianism) and deontological ethics (i.e., Kantian-inspired and others) are to be opposed to noncognitivist approaches to moral philosophy - such as the ones advocated by postmodernists and those inspired by the radical critique of modernity (and of liberal democracy in particular) undertaken by Nietzsche, Heidegger, Foucault and Derrida. ${ }^{12}$ As Kenneth

$"$ R. Bernstein, Beyond Objectivism and Relativism: Science, Hermeneutics, and Praxis (Philadelphia: University of Pennsylvania Press, 1983), p. 2.

12 I examined this problematic in my Ph.D. dissertation, "On the Genealogy of Modernity: Kant, Nietzsche, Foucault" (State University of New York at Stony Brook, 1994). 
Baynes has shown in NG, the constructivist account of practical philosophy advocated by these thinkers aims at specifying "a procedure for critically assessing the legitimacy of social norms and institutions by reference to a normative conception of practical reason" (NG 8). Moreover, by elaborating on the main arguments of these versions of constructivism, the latter is shown to constitute a highly defensible "clarification of the normative grounds" of social criticism, whose justification is "ultimately reflexive or recursive in the sense that there can be no higher appeal to something beyond the idea of that to which free and equal persons can rationally agree"(NG 2). Both Rawls's and Habermas's reading of Kant's political philosophy rejects the reduction of the problem of justice either to a teleological actualization in history (Hegelian-inspired reading of the "kingdom of ends") or to an instrumentalization of practical reason (either by the denial of the Kantian analogy between the categorical imperative and the universal principle of justice in the Rechtslehre or by turning the political-juridical into an extension of the moral foundations).

Since I am confined to investigating how Rawls's conception of justice as fairness succeeds in preserving the universalizable, normative foundations intrinsic to Kant's constructivism without falling back into foundationalism, I am assuming, from the outset, that there is a systematic continuity between Rawls's Theory of Justice of 1971 and his later writings leading to the 1993 volume on Political Liberalism. Justice as fairness, according to John Rawls, "is a theory of human justice and among its premises are the elementary facts about persons and their place in nature" (TJ 257). As opposed to Immanuel Kant's original conception of pure practical reason, Rawls stresses that fairness qua practical reasonableness is peculiar to human beings - and not to rational beings überhaupt. In effect, Kant seems to shift away from the non-demonstrable Faktum der Vernunft assumed in the second Critique towards a human practical reason in his later writings (notably MdS and political writings) so as to account for the tension between autonomy and heteronomy in the very "unsociable sociability" that characterizes human nature. Hence the modern problem of articulating ethics and political philosophy through a critical conception of human nature lies at the heart of Kant's critique of metaphysical foundations. For Kant, as Rawls rightly contends, the place of human persons in nature constitutes the counterpart to the Copernican revolution in theoretical philosophy (KrV), insofar as causality in the phenomenal realm can be experienced by humans both as object and subject of events in one single, sensible world. ${ }^{13}$ The transition from a theoretical account in $\mathrm{KrV}$ to a practical philosophy in $\mathrm{KpV}$ does not oppose nature to freedom in a dualism of "two worlds" - one sensible and another intelligible - but rather defines the limit-situations of thinking our own human finitude, at once as causa phaenomenon and as causa noumenon. As Pierre Kerszberg puts it,

${ }^{13}$ I am using the following abbreviations for Kant's works: KrV, KpV, KU, GMS, MdS (ed. W. Weischedel, Frankfurt: Suhrkamp, 1968). 
Freedom in the Kantian sense cannot be said to belong to the essence of man. The ability of human beings to choose between right and wrong, good and evil, does not proceed from their freedom. Rather, freedom is the beginning of a series which insinuates itself into the causal series of the world of experience. It is to be met with only in acting, and it works as the principle of action. ${ }^{14}$

As Kerszberg shows in his meticulous study of Kant's cosmic philosophy (both in the sense of Weltbegriff and of a weltbürgerlichen concept), "transcendental freedom is still part of the cosmic concept of philosophy". It is therefore a question of perspectivism whether one takes the standpoint of theoretical or practical reason when dealing with human agency in nature, in accordance with Kant's own distinction between negative and positive freedom. Rawls carefully contrasts Kant's intuitionism in the theoretical use of pure reason with the constructivism of his practical philosophy. According to Rawls, such is indeed the systematic, philosophical hallmark of Kant's transcendental idealism, namely, that the unity of reason stands or falls with the "two-world thesis". It seems, however, that Rawls succumbs somewhat to the very dualism he struggles to overcome - and Habermas has correctly detected it in the former's opposition of truth in theoretical reason to justice in practical reason. In order to avoid what he takes for a foundationalist predicament, Rawls views the original position "as a procedural interpretation of Kant's conception of autonomy and the categorical imperative" (TJ § 40) with the proviso that "the person's choice as a noumenal self" is taken as "a collective one" (TJ 257). The criticisms raised by utilitarians and communitarians against Rawls's theory of justice seem to converge on the correlated problems of maintaining, on the one hand, the Kantian priority of right/justice (Recht) over the good - or the universalizable principle of justice over the principle of utility - and a model-conception of the person in a given political culture, on the other hand. Although the former problem appears to be dealt with in TJ while the latter is only formulated in PL, I argue that they complement each other and are essential to a correct understanding of Rawls's constructivist theory of justice, as over against moral intuitionism and utilitarianism in both texts. It is thus my contention here that Rawls's political constructivism can be better understood in the very terms of its critical account of the foundations of a theory of justice, and more specifically, in light of his critical appropriation of Kantian moral constructivism.

One of the greatest pretensions (and, to my mind, one of the greatest merits) of Rawls's theory of justice is to provide us with an ethical-political conception of the normative foundations of social life. The theory of justice may be thus viewed as a universalizable procedure of construction capable of accounting for human sociality in constitutional, democratic societies, where claims to basic liberties and fair participation in social life allow for the pluralist coexistence of different, incompatible religious, philosophical, and moral beliefs. Therefore, at the very level of its foundation, the concept of justice is to practical philosophy what truth is to

${ }^{14}$ P. Kerszberg, Critique and Totality (Albany: SUNY Press, 1997), p. 14. 
the theory of knowledge (TJ § 3). According to Rawls, "a conception of justice characterizes our moral sensibility when the everyday judgments we do make are in accordance with its principles" (TJ 46). The two fundamental principles (the Equal Liberty Principle and the Difference/Equality Principle) formulated by the Rawlsian theory of justice, as well as the original devices (dispositifs) of the original position and reflective equilibrium, are to be understood in this precise context of foundation - if not in the sense of a Kantian Grundlegung (as in the GMS and $\mathrm{KpV}$ ) at least as a Begründung - insofar as they must be understood as formalprocedural rules capable of establishing normative criteria and determining results to be judged fair (beurteilen). Just as the sense of grammaticalness is presupposed in everyday practices of speaking one's mother-tongue (or at least "functioning" in a given language) and a rational faculty is presupposed in the conception of judgments and thoughts, the sense of justice and capacity for a conception of the good are inherent to the conception of moral persons, free and equal, living in a democratic society. "Justice as fairness", according to Rawls, seeks to unveil the fundamental ideas (latent in common sense) of liberty and equality, of an ideal social cooperation and the person. Rawls continuously reviews his theory of justice so as to better elucidate its foundations. In particular, Rawls addresses many of the questions raised by his critics as for his interpretation of Kant's moral philosophy, on the one hand, and as for the arguments he uses against utilitarian conceptions, on the other. As early as 1971, Rawls asserted that TJ sought to "bring together into one coherent view the ideas expressed in the papers... written over the past dozen years or so." The central topics of these essays were then taken up again, "usually in considerably more detair", so as to construe a TJ. "Theory of justice" was already understood as a philosophical analysis of what justice is, avoiding both metaethical and substantive exclusive approaches to ethics. Thus, Kant's moral philosophy, a refutation of eudaimonism, intuitionism, and utilitarianism, the rehabilitation of the concept of justice inherent to constitutional contractarianism classical-liberal (Locke) and radical-democratic (Rousseau) - the problem of constructivism, the question of the foundation of moral principles, the question of the just and the good (Aristotle) - these and other related problems are all thematized by the TJ. At the end of the book (TJ $\S 87$ ), Rawls reminds us that his conception of the foundations or justification of morals is to be distinguished from the two models that prevailed in the history of ethics, namely, the Cartesian deductive model (inferring a body of standards and precepts out of self-evident, moral first principles) and the naturalist model (definitions of moral concepts can be compared/reduced to nonmoral concepts). Rawls clings to the Socratic principle (TJ § 9) insofar as moral theory always brings us back to review our principles and judgments, and stresses that "justification rests upon the entire conception lof justice] and how it fits in with and organizes our considered judgments in reflective equilibrium" (TJ 579). Only then can we proceed to a "substantive theory of justice". By his implicit reformulation of a theory of society and of a theory of moral person, a theory of justice as fairness is supposed to strike us as being more defensible and more effective than any other version of contractarianism (TJ 584). 
This is of course understood to be extended to any other theory of society. If human beings want to live in society and keep all their cultural, religious, and moral differences they should subscribe to such a theory of justice. My main contention here is that the question of its foundations (Rawls's constructivism) underlies the entire development of concepts that structure the Rawlsian theory as a whole, being extended and more explicitly articulated with questions of political-practical order in later writings, notably in his lectures on "Kantian Constructivism in Moral Theory" (Columbia University, 1980) and in the volume on Political Liberalism. Even when he seems to concede to some form of theoretical retraction, Rawls ends up reformulating an original concept or its first version in TJ so as to deepen the central theses of his theory of justice. For instance, in PL Rawls indicates straightforwardly that the major problem with $\mathrm{TJ}$ lied in the inconsistencies between the account of stability (part III, in part. § 76, the problem of relative stability) and the rest of his magnum opus - prior to Habermas's criticisms in the Journal of Philosophy. In other words, the question of articulating a well-ordered society, conceived as a regulative ideal of a society that seeks to promote its wellbeing through the public conception of justice, with a basic notion of an "association of social cooperation". In spite of his insightful remarks on the idea of social union in TJ § 79, the question of sociality remains problematic in Rawls's conception of a hypothetical society strategically idealized in a form accepted by each citizen who also knows that all the others accept the same principles of justice, satisfied by the basic social institutions (TJ § 69). According to a theoreticalconceptual construction of the original position in $\mathrm{TJ}$, the two principles are the only ones to be effectively chosen by the parties for the realization of society tout court, i.e., to account for the state of civil society. The problem, as reformulated by Rawls in PL, is to sustain this theory as an alternative to utilitarian and intuitionist conceptions of morality underlying our liberal, democratic societies. In effect, the alliance of these apparently opposed traditions (the liberal and democratic contractarian models, respectively upheld by John Locke and Jean-Jacques Rousseau) constitutes the political-philosophical platform common to Kant, Rawls, and Habermas. Rawls's "Kantian interpretation" is precisely what marks him off from Habermas's appropriation of the same principle of universalizibility. The democratic pluralism of liberal societies, as opposed to the ideal speech situation of discourse ethics, is regarded as a problematic starting-point by Rawls, not so much for the diversity of religious, philosophical, and moral doctrines, but for the pluralism of comprehensive doctrines that prove themselves incompatible for not being accepted by all involved parties - Rawls resorts thus to a distinction between the public and the nonpublic viewpoints (non-private). To be sure, Rawls does not distinguish between the moral and the political in TJ (cf. PL Xv), the social contract being understood within moral philosophy: whatever is just always excels that which is better for society. A just well-ordered society must be founded in such a way that people will put up with all their religious, ethnic, and cultural differences, as free and equal persons who seek to live well. 
Habermas has also extensively written on the moral grounds of his political theory. Parallel to Rawls's account of competing models of morality in TJ, one finds in Habermas's main writings on Diskursethik (especially in MKH and Justification and Application) similar arguments to sustain a postmetaphysical reformulation of Kant's deontological, procedural universalism in moral philosophy. One important difference to be signaled is that while Rawls seeks to focus on a specifically political account of justice - as seen above, to the point of departing from a moral doctrine - Habermas maintains the moral basis of his political theory, although subscribing to Hegel's critique of Kant's moral view, which allows for Rawls's contention that Habermas remains within a comprehensive view of practical rationality. It can be seen that, beyond their similarities and differences, Rawls and Habermas are both dealing with the same problem of sustaining a universalizable model of ethics and political philosophy that accounts for the diversity of goods to be sought empirically and the unity of social binding that makes political institutions desirable for all. It is in this sense that I place the question of public autonomy at the intersection of human rationality and sociality. ${ }^{15}$ The debate opposing John Rawls and Jürgen Habermas helps us thus reexamine the specific question of their appropriation of Kant's conception of autonomy in their respective conceptions of public reason. Both Rawls's and Habermas's "procedural universalism", insofar as they resort to a normative, universalizable conception of practical reason, follows Kant's proceduralism at the same time that it reverses the latter in their attempt to ground and justify sociality in our constitutional, liberal democracies. The theory of communicative reason, according to Habermas, proposes to overcome the late capitalist crisis of legitimation in our fin-de-siècle modernity, without falling back in the aporias of a critique of ideology and philosophies of consciousness / subject, on the one hand, and avoiding the pitfalls of relativism, skepticism and historicism, on the other, in an overt attack upon postmodern criticisms of modernity. Habermas reclaims thus the Kantian legacy of a normative foundation for the political sphere, at the same time that he maintains the separation of morality and legality, and the primacy of a communicative normativity regulated by rational discourse, shared by all and capable of guiding human action in democratic, pluralist societies. Political questions are to be debated, therefore, within the context of a discourse ethics, founded in the form of an argumentative, moral logic, hence both normative and universalizable. The Habermasian theory succeeds in articulating the question of normativity with the political, social question of institutionalization, in the very conception of an integrated model which differentiates the systemic world of institutions (defined by their capacity of responding to the functional demands imposed by the environment/context) of the lifeworld (Lebenswelt, i.e. forms of cul-

15 I am indebted to Professor Bemstein's usage of the term "sociality" - juxtaposed to sociability and socialization - to denote the intersubjetivity of social life, inherent in our political existence as human beings. Cf. Richard J. Bernstein, "Rethinking the Social and the Political", Graduate Faculty Philosophy Journal 11/1 (1986): 111-130. 
tural, societal and personal reproduction that are integrated through the norms consensually accepted by all participants in the social world). In effect, it is the rationalization of the Lebenswelt which renders possible the differentiation of autonomous subsystems, opening thus the utopian horizon of a civil society in which the spheres of action formally organized of the bourgeoisie constitute the foundations of the posttraditional social world of human beings (private sphere) and citizens (public sphere). According to Habermas, the normative thrust of democracy, in a social-theoretical sense, can be expressed in the idea that the satisfaction of functional needs of action systematically integrated must find its limits in the integrity of the lifeworld, i.e. in the demands of the spheres of action which are socially (i.e., communicatively) integrated (TKH, vol. 1, p. 307).

Although I cannot elaborate on this question here, it is my contention that Sandel's criticisms addressed to Rawls's liberalism may as well be applied to the Habermasian attempt to articulate a Kantian proceduralism with a Hegelianinspired view of ethical life. Indeed, a similar problem lies at Habermas's procedural formulation of an ideal speech situation, which can be solved with the support of an analysis of civil society's voluntary associations that secure democratic values against the state and economic colonizations of the lifeworld. In his later formulation of his procedural model of deliberative, participatory democracy in BFN, Habermas contends that his theory of communicative action stands as a third way between a systemic-theoretical sociology of law (such as the one advocated by Niklas Luhmann) and a liberal, universalist theory of justice (such as John Rawls's). After having developed a theory of justice "in vacuo", says Habermas, Rawls recasts the "old problem of how the rational project of a just society, in abstract contrast to an obtuse reality, can be realized after confidence in the dialectic of reason and revolution, played out by Hegel and Marx as a philosophy of history, has been exhausted - and only the reformist path of trial and error remains both practically available and morally reasonable" (BFN 57). For Habermas, Rawls's problem appears as "the return of a repressed problem," insofar as it recasts the modern model of natural law (social contract) in procedural terms ("original position"). The normative features of the Rawlsian model - which, according to Habermas, can be equally characterized as "liberal" and "socialdemocratic" depending on whether one takes on an Anglo-American or a Continental, European terminology - come under attack for idealizing the "well-ordered society," with its mere constructs ("artificial entities"), not to "be identified with flesh-and-blood citizens who would live under the real conditions of a society erected on principles of justice" (BFN 58). Hence Habermas claims to spot Rawls's later problematic of "self-stabilization" (TJ § 86) already at the level of the latter's early formulation of a "thin theory of the good," inevitably prone to fall into Hegel's critique of Kant's Moralität / Sittlichkeit. According to Habermas, "the selfstabilization of a well-ordered society is therefore based not on the coercive force of law but on the socializing force of a life under just institutions, for such a life simultaneously develops and reinforces the citizens' dispositions to justice" (BFN 58). I think it is precisely at this level of the historicity and sociality of an intersub- 
jectively constituted self that Habermas seeks to bring Hegel's critique of Kant so as to corroborate the communitarian critique of the self in Rawls. As McCarthy remarks in his Introduction to the English Translation of MKH, since philosophy or ethics cannot provide an answer to the question "How should we then live?" - as opposed to Kant's procedural universalism - in order for a principle to be universalizable it must be acceptable to all participants in a practical, public discourse. And in this distinctive feature vis à vis Kant's transcendental subjectivity of a pure practical reason, McCarthy - like Habermas - places Rawls's "original position" as a monological device of representation invoked by "rational egoists prudently contracting behind a veil of ignorance" (MKH viii). That is why Rawls's later attempt to articulate his political constructivism with the abstract theory of reflective equilibrium can easily lead to anti-Kantian interpretations, in sheer opposition to his original "Kantian interpretation." It is no wonder that Habermas invokes Richard Rorty's reading of Rawls as the philosopher of liberalism in order to call into question the very idea of resorting to a particular model (US liberal democracy) when facing the same charges Hegel raised against Kant's "abstract universalism" and "terrorism of pure conviction" (MKH 195f.). For Rorty develops a veritable "immanent critique" of Rawls's liberalism, in what is supposed to be an ironical, radical appropriation of the pragmatism one finds in Peirce, James, and Dewey. In fact Rorty's charges of historicism raised against Rawls's liberalism attest to this problem in Rawls's formulation. Although Habermas's point is well taken, I do not think Rorty's criticisms aim only at the internal difficulties of Rawls's theory. After all, Rorty draws also very close to Rawls's noncomprehensive, political conception of justice insofar as his staging of the primacy of democracy (politically conceived) over philosophy is precisely what motivates his unorthodox pragmatism. However, as unveiled in Bernstein's critique of Rorty's reading of Rawls and Habermas, what is at stake is not a historicist basis creating the conditions as it were for the emergence of a liberal-democratic political culture, but rather to account for the foundations (both moral and political) of democracy. ${ }^{16}$

McCarthy's reading of the Rawls-Habermas debate can be invoked here in our attempt to recast Kant as the "Schiedsrichter" between Rawls and Habermas, more specifically, in their respective constructivist and reconstructivist interpretations. McCarthy's terminology (constructivism vs. reconstructivism) is a felicitous rapprochement of these two political thinkers, at their very attempt to provide us with a philosophical justification of political institutions and forms of government. In effect, political philosophy thus understood maintains its nonempirical thrust (even with a nonfoundationalist intent) at the same time that proves useful for theoretical, epistemological, and methodological researches in the social sciences. Habermas's earlier criticism of positivist, hermeneutical and phenomenological approaches to the social sciences is very instructive - e.g., in Zur Logik der

${ }^{16}$ Cf. R. Bernstein, "Rorty on Liberal Democracy and Philosophy" and "Rorty's Liberal Utopia," in The New Constellation: The Ethical-Political Horizons of Modernity/ Postmodernity (Cambridge, Mass.: MIT Press, 1992), pp. 230-292. 
Sozialwissenschaften (1967) and Erkenntnis und Interesse (1968) - insofar as it attests to the contemporary challenge imposed by social and political theory, in Bernstein's formula, to be at once "empirical, interpretative, and critical" ${ }^{17}$ In this regard, it must be recalled that Habermas's appropriation of Kant is reconstructive both in a philosophical and a sociological sense. As in a model of proceduralism, both Rawls and Habermas ground ethics in universal terms, transcending all cultural, empirically constituted norms. For Rawls, it is in the original position that the universalizibility principle is at work, in the principles of justice chosen by the parties under the veil of ignorance. For Habermas, discourse ethics is itself grounded in empirically-based understandings of the praxis and conditions of discourse. Habermas's discourse ethics, while charting out the necessary conditions of the ideal, democratic speech community also relies on "forms of socialization and social reproduction that can be counted upon to foster the requisite capacities and motivations" for engaging in ideal discourse (KCR 47-48). Theory must be undertaken with a practical intent, articulating praxis and action, attesting to what Bernstein identifies with "the dominant concern of the most influential philosophic movements that have emerged since Hegel." ${ }^{18}$ This focus on praxis, furthermore, is characteristic of both the Frankfurt School in general and Habermas in particular. As Bernstein has shown, Habermas's entire work can be regarded "as a rethinking and rewriting of the Dialectic of Enlightenment," as he systematically seeks to fulfill the emancipatory promise of modernity and overcome its shortcomings and contradictions. ${ }^{19}$ It is thus a question of relating our present (political) praxis to social action, particularly to the "purposive-rational" (Zweckrationalität) action that, according to Max Weber, pervades every domain of modern culture and society. And yet, as Bernstein has pointed out, "the meanings of the rationalization of purposive-rational actions and communicative actions are categorically distinct." While purposive-rational actions can be rationalized in terms of systemic integration, systematically distorted communication can be mediated towards mutual understanding and consensual regulation of conflicts. As Bernstein puts it so well,

[Habermas] wants to do justice to the integrity of the lifeworld and social systems, and to show how each presupposes the other. We cannot understand the character of the lifeworld unless we understand the social systems that shape it, and we cannot understand social systems unless we see how they arise out of activities of social agents. The synthesis of system and lifeworld orientations is integrated with Habermas's de-

17 R. Bernstein, The Restructuring of Social and Political Theory (Philadelphia: University of Pennsylvania Press, 1976), p. 235.

18 Cf. R. Bemstein, Praxis and Action: Contemporary Philosophies of Human Activity (Philadelphia: University of Pennsylvania Press, 1971), p. xiii.

19 R. Bernstein, "An Allegory of Modernity/Postmodernity: Habermas and Derrida," in The New Constellation, op. cit., p. 207. 
lineation of different forms of rationality and rationalization: systems rationality is a type of purposive-rational rationality, lifeworld rationality is communicative rationality. ${ }^{20}$

To be sure, there is no clear-cut separation of lifeworld and systems rationalities, since it is precisely because of the systemic colonization of the lifeworld that social actors can have more and more access to its general structures and are urged to seek integration amid all complex differentiations, with a view to attaining emancipation and understanding. Hence, to the structural differentiation of the lifeworld in its social integration, cultural reproduction and personal socialization, there must be an interactive differentiation of the systemic institutions steered by money and power (economy and bureaucratic administration). What is at stake, after all, is the institutionalization of the social world, beyond traditional accounts of society and state. It is in this sense that McCarthy goes as far as to observe that much of Habermas's writings can be understood "as a protracted examination of, and barriers to, the implementation of practical discourses" (KCR 48). Hence the proceduralist conception of deliberative democracy parallels that of Rawlsian reflective equilibrium, as the discourse ethics marks out the conditions of discourse as the procedure or form of discourse as the central praxis of democracy. More specifically, this proceduralist conception "applies the idea of justification by appeal to generally acceptable reasons to the deliberations of free and equal citizens in a constitutional democracy." The central focus and example of such deliberation is "the institutionalization of political autonomy, that is, of the public use of reason in the legal-political domain." In this domain, reasoned agreement involves three sorts of practical reasoning, "pragmatic discourse about how best to achieve our ends, ethical discourse concerned with goods, values, and identities, and moral discourse concerning what is just, fair, or equally in the interest of all". Such an agreement will further require "negotiation and compromise which, if the agreements arrived at are to deserve to be called reasonable, will themselves have to be regulated so as to ensure a fair balancing of interests". As McCarthy sums it up,

Thus the normative conception of democratic deliberation that Habermas proposes weaves negotiations and pragmatic deliberations together with ethical and moral discourses, under conditions that warrant a presumption that procedurally correct outcomes will be ones with which free and equal citizens could reasonably agree. $\mathrm{He}$ conceives of the basic principles of the democratic constitutional state primarily as a response to the question of how such conditions of rational deliberation can be implemented both in official governmental arenas and in unofficial arenas of the political public sphere (KCR 48f).

McCarthy finds here an initial divergence between Rawls and Habermas, in that the latter defines "public reason" so as to include the "unofficial arenas of the political public sphere". Indeed, these unofficial arenas, "independent public forums, distinct from both the economic system and the state administration, having

2o Cf. R. Bernstein, ed., Habermas and Modernity. (Cambridge, Mass.: MIT Press, 1985), p. 22. 
their locus rather in voluntary associations, social movements, and other networks and processes of communication in civil society - including the mass media - are for Habermas the basis of popular sovereignty" (KCR 49). Ideally, not only are these unofficial forums "translated via legally institutionalized decision-making procedures - for example, electoral and legislative procedures - into the administrative power of the state", but also as McCarthy adds,

In this model of a deliberative decentering of political power, the multiple and multiform arenas for detecting, defining, and discussing society's problems, and the culturally and politically mobilized publics who use them, serve as the basis for democratic self-government and thus for political autonomy (KCR 49).

Rawls's concept of "public reason", on the other hand, excludes such unofficial forums - i.e., the unofficial arenas of public discourse which for Habermas are the source of democratic self-rule and political autonomy (PL Lecture VI: The Idea of Public Reason, § 1-3). McCarthy concludes by noting that Habermas's proceduralist conception of democracy, as rooted in the ongoing processes of public reason, remains formal and empty of content:

The constitution is viewed as a "project" that is always incomplete and subject to the ongoing exercise of political autonomy, as shifting historical circumstances demand. Because the public use of reason is ineluctably open and reflexive, our understanding of the principles of justice must remain so as well. It is for this reason that Habermas limits himself to reconstructing the conditions and presuppositions of democratic deliberation and leaves all substantive questions to the public use of reason itself. His discourse theory of deliberative democracy focuses exclusively on the procedural aspects of the public use of reason and derives the system of rights from the idea of legally institutionalizing it [i.e., the public use of reason]. It can leave more questions open because it entrusts more to the process of rational opinion- and will-formation (KCR 49).

As noted above, Rawls distinguishes public from nonpublic uses of reason, in PL, by reference to governmental and quasi-governmental venues and functions (e.g., parliamentary debates, administrative acts and pronouncements, and the workings of the judiciary, but also with political campaigns, party politics, and even the act of voting) (PL $214 \mathrm{ff}$.). "Nonpublic" reason, on the other hand, is connected with nongovernmental venues and functions - e.g., with churches, universities, professional groups, and voluntary associations in civil society (PL 213, 220) - that is, largely with the unofficial networks of private people communicating about public matters that Habermas considers to be the nervous system of the political public sphere (KCR 50). Rawls's conception of public reason and its limits, includes a duty of civility, by which citizens see themselves as obligated to a public use of reason in publicly discussing fundamental issues of justice (PL 217-18). Being thus "reasonable", in Rawls's sense of the term, they "don't appeal to the whole truth as [they] see it", but seek to show how their positions can be supported by political values. Hence, as McCarthy remarks, "the picture of public reason adumbrated in these limits and duties is likely to give pause to theorists 
with a more robust conception of democratic discourse. It would, in particular, be unacceptable to Habermas, who is no less interested in public criticism than in public justification" (KCR 51). Rawls seems committed to a more restricted notion of public reason - one which, for the sake of achieving agreement in a pluralistic society, apparently restricts the critical function of reason in public venues. Another point of rupture is the primacy of the observer's perspective in Rawls, as opposed to the participant's perspective in Habermas. And yet the observer cannot be taken for an ideally impartial one - as in Thomas Nagel's "view from nowhere". The neutral standpoint, for Rawls, simply means that there must be no reference to moral goods when affirming the primacy of justice (PL $191 \mathrm{ff}$.). Hence Rawls maintains that "justice as fairness is not procedurally neutral," in that its principles are substantive and "express far more than procedural values, and so do its political conceptions of society and person, which are represented in the original position" (PL 192). It is a question therefore of "neutrality of aim", in search of "a common ground as the focus of an overlapping consensus", so that no particular comprehensive doctrine be favored. It is in this particular feature that McCarthy criticizes Habermas's optimism regarding the possibility of achieving consensus on decisive norms. According to McCarthy, Habermas should follow Rawls's "greater abstraction", as the latter suggested in his reply, and move to meta-values, "for example, from different preferences to freedom of choice, from opposed beliefs to liberty of conscience, from conflicting values to rights of privacy, and the like" (KCR 56). McCarthy then proceeds to recommend a synthesis of both attitudes, the public reason endorsed by both participants and observers:

Stylizing somewhat, we might regard the two basic aspects of the reasonable as standing in a tension. [...] As "participants", to use Habermas's terminology, we want to justify our actions to others on grounds that all could rationally accept. As "observers", however, we note the fact of reasonable pluralism and anticipate that some of the reasons acceptable to us will be unacceptable to others. How are we to combine these two points of view? [...] Rawls's strategy is to discount the pluralism in advance, so to speak, by restricting public reason to the ambit of an overlapping consensus. There I argued, in effect, that this deprives the participant's perspective of its proper weight, and I suggested that the imbalance results from the way Rawls now builds the problem of stability into his normative-theoretical approach (KCR 58).

According to McCarthy, Rawls in effect cedes a certain primacy to the observer's perspective: "the concern with stability in light of the fact of reasonable pluralism limits the scope of what may count as good reasons in matters of public justification. His understanding of the principle of moral motivation - a principle that could serve as the motto of Habermas's discourse ethics - supports this reading". As Rawls observes,

Since many doctrines are seen to be reasonable, those who insist, when fundamental political questions are at stake, on what they take as true but others do not, seem to others simply to insist on their own beliefs... They impose their beliefs because, they say, their beliefs are true, and not because they are their beliefs. But this is a claim all 
equally could make; it is also a claim that cannot be made by anyone to citizens generally. So when we make such claims, others, who are themselves reasonable, must count us unreasonable (PL 61).

For Rawls, that would be the problem with maintaining a comprehensive view, even with many reasonable ones, as a "sectarian" standpoint, likely to bring about political division. The point is that "once we accept the fact that reasonable pluralism is a permanent condition of public culture under free institutions, the idea of the reasonable is more suitable as part of the basis of public justification for a constitutional regime than the idea of moral truth" (PL 129). This would secure observers in a liberal democracy to avoid the unreasonableness and prefer to keep pluralism reasonable. To the extent that he seeks to promote the fact of reasonable pluralism so as to replace Kant's practical foundationalism - beyond his problematic account of Kant's fact of reason in the Stanford paper - I think that Rawls's argument in favor of a supposedly nonmetaphysical political constructivism in opposition to Kant's moral constructivism succeeds in preserving the primacy of justice over the good and the universalizable thrust of the latter in strictly political terms. In this sense, Rawls seeks to avoid the idealized standpoint of a communicative community, although his device of representation in the original position seems to be exposed to the same sort of criticism. In this sense, McCarthy misses here the problematic opposition between truth and right/justice sustained throughout Rawls's writings from TJ to PL. As he writes in PL 243,

It is only [...] by accepting that politics in a democratic society can never be guided by what we see as the whole truth, that we can realize the ideal expressed by the principle of legitimacy: to live politically with others in the light of reasons all might reasonably be expected to endorse.

That is the very reason why Rawls endorses an anti-Hegelian view of freedom, in his reply to Habermas, who reconstructs Enlightenment rationality in terms of a normativity autonomously and rationally created within the community of rational agents seeking understanding through communication. Habermas's Kantian rationalism cannot be maintained without his explicit endorsement of Hegel's sittliche dialectic of society and freedom, even though Habermas categorically rejects an objective teleology. Habermas clearly seeks to avoid the abstractness of Kant's "narrow conception of morality", as opposed to a Hegelian-inspired materialist conception of society (MKH 210f.). As McCarthy characterizes Habermas's reconstruction, the key to commmunicative rationality is the appeal to reasons or grounds - the unforced force of the better argument - to gain intersubjective recognition for such claims. For Habermas, language and sociality entail each other: humans become social as they acquire and develop communication abilities, very much along the Hegelian phenomenological conception of experience and self-consciousness processes. Habermas's moral conception of political, public reason is also unveiled in his critique of Freud's metapsychological conception of the unconscious. Habermas, like Lacan and others from the French Left, endorses the linguistification of the unconscious (the unconscious being structured like a 
language). If the theory of communicative reason involves a procedural reformulation of the categorical imperative, it does so by submitting "my" maxims to others for purposes of discursively testing their claim to universal validity, rather than ascribing to others as valid those maxims I can will to be universal laws, so that it reverses the Kantian proceduralism. As McCarthy remarks, the emphasis shifts from what each can will without contradiction to what all can agree to in rational discourse. Validity construed as rational acceptability is not something that can be certified privately; it is tied to communication processes in which claims are tested argumentatively by weighing reasons pro and con (KCR 45f.). Accordingly, the aim of his discourse ethics is solely to reconstruct the moral point of view from which questions of right can be fairly and impartially adjudicated. The shift away from Kant's solitary, reflecting, moral consciousness to the community of moral subjects in dialogue is the main distinctive feature of a communicative reconstructivism. One can understand why Habermas, in his criticisms addressed to Rawls, will insist on the intersubjective constitution of discursivity and will oppose thus the latter's monological contract behind a veil of ignorance. As McCarthy remarks, Rawls represents only the "rational" directly and the "reasonable" indirectly, through the conditions of deliberation; whereas Habermas, because of the role that discourse plays in his theory, wants directly to represent the rational and reasonable deliberation of agents who have themselves adopted the moral point of view. Consequently, Habermas does not lean as heavily as Rawls does on the distinction between the rational and the reasonable, most often using them interchangeably to connote a capacity for and sensitivity to the weighing of reasons in speaking and acting (KCR 46f.). ${ }^{21}$

Of course, even the comparatively more modest program of attempting to build "simply" a theory of justice which claims validity beyond the bounds of a particular culture still faces various relativist attacks. Habermas seeks more universal grounds by way of action theory: his connecting his theory of justice to action theory is meant to show that our basic moral intuitions are rooted in something deeper and more universal than particularities of our tradition. The task of moral theory, in his view, is reflectively to articulate, refine, and elaborate - that is, to "reconstruct" - the intuitive grasp of the normative presuppositions of social interaction that belongs to the repertoire of competent social actors in any society (KCR 47).

As for Rawls's "Kantian interpretation," what is at stake is primarily to recast the Kantian foundations of ethics. Besides its refusal to ground the supreme principle of morality in a conception of the good or in a principle of utility, the Kantian procedure refuses the intuitionist thesis, according to which pure or sensible intuition or the experience of the senses, instincts, and emotions could found morals. In its broad definition, Rawls conceives of intuitionism as "the doctrine that there is an irreducible family of first principles, which have to be weighed against one

${ }^{21}$ Cf. Jürgen Habermas, The Theory of Communicative Action, trans. T. McCarthy (Boston: Beacon, 1984), vol. 1, pp. 1-141. 
another by asking ourselves which balance, in our considered judgment, is the most just" (TJ 34). On the one hand, Rawls maintains the moral-political correlation established by Kant, as well as the distinction between legality and morality. On the other hand, he seeks to recover the binding force of the principle of justice inherent to Kant's appropriation of the liberal, democratic conception of contract, as a regulative idea of practical reason. According to Rawls, universalizability and the primacy of right over the good are precisely what allow for a nonmetaphysical, detranscendentalized formulation of the principles of justice in reflective equilibrium. It is in this sense that Rawls emphasizes the strictly political-philosophical character of the foundations of a theory of justice. By recasting Kant's constructivism, Rawls aims at the normativity of practical reason in a contractarian context, ordered by a constitution and formed by free, morally equal persons, historically and socially conditioned - and not in a supposedly neutral standpoint. Rawls's contractarianism combines thus the Lockean principle of tolerance with Rousseau's general will, already appropriated by Kant. In the conception of Recht (justice/right) lies an articulation between the moral-rational Sollen and the politicalconstitutional Wollen capable of carrying out the "volonté générale" of the social contract. According to Kant, "the will of all individual men living in a legal constitution, according to principles of freedom (the distributive unity of the will of all) is not enough for this end [leading to perpetual peace], but that all together will this state (the collective unity of the united will)". Hence the role of political philosophy in the construction of a fair society ordered according to the rational principles of freedom that make us act out of duty.

McCarthy suggests that solidarity translates into a concern for the common good which seems implicit in Kant's notions of respect for persons and "the community of ends" as the ideal moral community, hence combining Kantian ideal of personality with the Hegelian-inspired interdependence between self and commmunity:

In Habermas's discourse ethics, which grounds (justifies, give reasons for choosing such and such) norms upon the reasoned agreement of those subject to them, equal respect for individuals is reflected in the freedom of each participant to respond with a yes or a no to reasons offered by way of justification and concern for the common good in the requirement that each participant take into account the needs, interests, and feelings of all others and give them equal weight to her own. Hence the actual practice of moral and political discourse depends on forms of socialization and social reproduction that can be counted upon to foster the requisite capacities and motivations (KCR 47f.).

Habermas, as noted above, developed his critical reconstructivism in function of the Hegelian critique of Kantian abstract morality. Both Habermas's reconstructivism and Rawls's constructivism refer us indeed back to Kant's fact of reason, which they interpret as an unsuccessful, dogmatic blindspot in the latter's practical philosophy, betrayed by a solipsist, transcendental conception of the self. And yet, as Kerszberg aptly remarks, 
The Faktum of practical reason is not an ordinary fact in the sense of Tatsache. It is the consciousness of moral law, that is, the medium through which reason speaks to itself on the occasion of moral duty that transcends the limitations of the material sphere of experience...In the cau of practical reason and its law of freedom, the power of the Faktum is such that imagination is left with nothing to do when reason applies the moral law to sensible objects: the mediation is entirely provided by the understanding $[\ldots]^{22}$

The faculties of cognition are to be understood within their respective domains, and Kant was very careful in his articulation of nature and freedom, even in the KU. If Kant apparently endorses the primacy of practical over theoretical reason, at the same time he emphasizes their unity:

...if pure reason of itself can be and really is practical, as the consciousness of the moral law shows it to be, it is only one and the same reason which judges a priori by principles, whether for theoretical or practical purposes (KpV 121).

The fact that pure reason is practical is thus parallel to the very reality of the categories and things-in-themselves which cannot be approached by theoretical reason - since knowledge of the suprasensible is impossible - but only through its practical use, by requiring the "practical postulates" of reason. If Kant presupposes a metaphysical conception of human nature - insofar as humans are citizens of two worlds, the phenomenal and the noumenal - it avoids the teleological, metaphysical perfectionism but rather allows for the articulation of both faculties (theoretical and practical) with the major thesis that, according to the teleological principle, the final purpose of nature is "humanity" (Menschheit), hence the humanization of the human species taken as an ethical, historical community (KU 298, 434-5). The Kantian principle of universalizability, according to Rawls, must be understood in light of the unity of the Critiques (the problem of the transcendental deduction) but it cannot overcome the "two-world thesis," insofar as Rawls interprets Kant's attitude towards the Faktum der Vernunft. To be sure, as O'Neill has remarked, Kant's critique avoids the foundationalism of Cartesian rationalism by the very dictinction of the uses of pure reason. ${ }^{23}$ Since Rawls seeks not to do injustice to Kant, constructivism is conceived as a more defensible model of morality than intuitionism, and yet seems doomed to its metaphysical dualism. According to political constructivism, a theory of justice as fairness is the most appropriate one for pluralist, democratic societies precisely because it turns out to be the most reasonable of all, the one which best translates the idea of an overlapping consensus. Political constructivism does not aim at opposing intuitionism as such, but only proves to be more fundamental and comprehensive from a conceptual standpoint.

22 Cf. P. Kerszberg, Critique and Totality, op. cit., p. 132.

${ }^{23}$ Cf. Onora O'Neill, "Vindicating reason", art. cit., p. 290; id., Constructions of Reason: Explorations of Kant's Practical Philosophy (Cambridge University Press, 1989), pp. 206-218; "The Method of A Theory of Justice", in O. Höffe (ed.), op. cit. 
Rawls uses thus the procedural representation of the categorical imperative (required by pure practical reason in the formulation of reasonable, universalizable maxims) so as to construct the content of a political conception of justice (in TJ, the two principles of justice are chosen by the parties in the original position in order to represent their societal interests, although the original position is not itself constructed. As a procedural device of representation, the original position is said to be simply laid out, insofar as it "exhibits reasonable conditions to impose on the parties, who as rational representatives are to select public principles of justice for the basic structure of such a society" (PL 103). Rawls contrasts thus the reasonableness and rationality of citizens (in their moral capacities for a sense of justice and for a conception of the good) with the rationality of the parties:

Citizens' capacity for a conception of their good in a manner suited for political justice is modeled within the procedure by the rationality of the parties. By contrast, citizens' capacity for a sense of justice is modeled within the procedure itself by such features as the reasonable condition of symmetry (or equality) in which their representatives are situated as well as by the limits on information expressed by the veil of ignorance (PL 104).

Although it is not explicitly developed in TJ, the reasonable/rational distinction expresses the Kantian priority of right over the good as the original position represents the standpoint of noumenal selves ( $\mathrm{TJ} \S 40$ ) where the veil of ignorance is said to be thick rather than thin and the parties to be symmetrically situated.(PL $24 \mathrm{n} .27)$ In order to strike a balance between the rational interests of different ethnic, cultural groups and the reasonable constraints that are to model the original position so as to make it fair, the deliberations of the former must be subject to the latter. Rawls is ultimately addressing two questions of foundations, namely, "what conceptions of society and person are appropriate so as to found a just society?" and "how do they arise?", or "by which procedure are they modeled?" His answer remains faithful to Kantian constructivism precisely because the principles of practical reason (both reasonable and rational) and the modelconceptions of society and person must be complementary. (PL 107) By way of conclusion, as Carlos Thiebaut put it, "Rawls's contribution proves itself to be contractarian insofar as the social contract theory is Kantian. ${ }^{24}$ In this sense, Rawls's political liberalism remains much closer to Kant's political autonomy than Habermas wants to believe. Even when Rawls seeks to go beyond Kant's moral constructivism and thus opposes his political conception of autonomy to the former's moral autonomy, what is at stake is the refusal of transcendental idealism in a nonfoundational theory of justice. Despite its shift from a comprehensive doctrine of justice in his 1971 masterpiece, Rawls's later political conception of justice only recasts Kant's procedural device of self-determination insofar as social agency is inevitably caught in reflective equilibrium.Both the private and the public spheres concur, at the very level of the mediation between popular sovereignty

${ }^{24}$ C. Thiebaud, in Contrato Social: Ontem e Hoje, ed. P. Krischke (São Paulo: Cortez, 1994), p. 284. 
and human rights anticipated by Kant, to account for a complex differentiation of the social world, as the colonization of the Lebenswelt by economic and political subsystems attests to its increasing rationalization, as "legal autonomy demands that the addressees of law be able to understand themselves at the same time as its authors". 